\title{
Team Monitoring, Does it Matter for Team Performance? Moderating role of Team Monitoring on Team Psychological Safety and Team Learning
}

\author{
Tarman Budianto $^{1,2, *}$, Ely Susanto ${ }^{3}$, Sari Sitalaksmi ${ }^{1}$, Gugup Kismono ${ }^{1}$ \\ ${ }^{1}$ Department of Management, Faculty of Economics and Business, Universitas Gadjah Mada, \\ Yogyakarta, 55281, Indonesia \\ ${ }^{2}$ Personnel Education and Training Center, Ministry of Education and Culture, Indonesia \\ ${ }^{3}$ Department of Public Policy and Management, Faculty of Social and Political Sciences, Universitas \\ Gadjah Mada, Indonesia
}

\begin{tabular}{|c|c|}
\hline ABSTRACT & ARTICLE INFO \\
\hline $\begin{array}{l}\text { Introduction: The use of work teams is a strategy that allows } \\
\text { organizations to move faster and more proactively. Team performance is } \\
\text { an interesting issue that needs to be studied more extensively. } \\
\text { Background Problems: Team psychological safety and team learning } \\
\text { have a positive effect on team performance. But in some of the literature, } \\
\text { psychological safety has also been shown to have a negative impact on } \\
\text { teams when team monitoring is low. This research was conducted to } \\
\text { investigate the moderation role of team monitoring and the influence of } \\
\text { team learning and team psychological safety on team performance. } \\
\text { Novelty: This research contributes new insights related with team } \\
\text { monitoring and its interaction to team learning and team psychological } \\
\text { safety on team performance. Team psychological safety has been proven } \\
\text { to be able to directly influence team performance indirectly through team } \\
\text { learning, but we tested the two separately. Research Methods: This } \\
\text { study involved } 215 \text { respondents who joined } 38 \text { teams. The collected data } \\
\text { were analyzed using a regression analysis and bootstrap techniques. } \\
\text { Findings: Team monitoring has been shown to have a moderate role in } \\
\text { influencing team learning on team performance, but it has not been } \\
\text { proven to influence team psychological safety on team performance. The } \\
\text { learning and psychological safety of each team proved to have a direct } \\
\text { effect on team performance. Conclusion: This paper can guide managers } \\
\text { since, at a certain level team monitoring can improve team performance, } \\
\text { but too much team monitoring actually has no effect on team } \\
\text { performance. Managers need to consider team monitoring policies } \\
\text { carefully, to optimizing team performance by managing team learning } \\
\text { and building team psychological safety. }\end{array}$ & $\begin{array}{l}\text { Article history: } \\
\text { Received in } 28 \text { February } \\
2020 \\
\text { Received in revised form } \\
17 \text { Maret } 2020 \\
\text { Accepted } 6 \text { April } 2020 \\
\text { Keywords: } \\
\text { Team Monitoring, Team } \\
\text { Performance, Team } \\
\text { Learning, Team } \\
\text { Psychological Safety } \\
\text { JEL Code: } \\
\text { D89, H11, D83, D91 }\end{array}$ \\
\hline
\end{tabular}

\footnotetext{
* Corresponding Author at Department of Management, Faculty of Economics and Business, Universitas Gadjah Mada, Jalan Socio Humaniora No. 1, Yogyakarta 55182, Indonesia.

E-mail address: tarman_060708@yahoo.com, elysusanto@ugm.ac.id, sarisitalaksmi@ugm.ac.id, gugup_kismono@ugm.ac.id.
} 


\section{INTRODUCTION}

Describing performance is the bedrock of studies into organizational behavioral research (Barrick, Mount, \& Li, 2013). Previous literature has shown that the use of work teams can help organizations to move faster and more proactively (e.g., Kerr \& Tindale, 2004; Kozlowski \& Chao, 2012). This causes a greater focus on how to strive to achieve maximum team performance (Salas, Stagl, \& Burke, 2004). Langfred (2004) states the importance of the study of intra team trust when examining team functions. Studies related to the process that transmits the effects of trust have been recognized as an important part of advancing the understanding of team performance (Mayer \& Gavin, 2005; McAllister, 1995), but empirical examinations of these are still scarce. So it is necessary to advance the understanding of how trust (and its various derivatives) can affect team performance.

Previous literature shows that how trust influences team performance has received much attention from researchers into organizational behavior, but little is known about how trust affects team performance (Dirks \& Ferrin, 2001). In this regard (how trust affects team performance), De Jong and Elfring (2010) suggest that team reflection, team monitoring, and team efforts have an important role in transferring the effect of trust onto team performance. Edmondson's study (1999) shows that team learning (a concept that is closely related to reflexivity) mediates the influence of team psychological safety (a concept that is closely related to mutual trust) on team performance. Trust can be related to the perspective of the theory of purposeful work behavior (TPWB) which suggests that the work's context can facilitate or limit the extent to which individuals are expressing himself so that it influences whether an individual's perceived work effort is viewed as something meaningful (Barrick et al., 2013). So we argue that team monitoring as a representation of a positive form of attention (De Jong \& Elfring, 2010), can strengthen team learning and team psychological safety as a control mechanism for improving team performance. This research aims to investigating the role of team monitoring in transmitting the effects of trust into the influence of team learning and team psychological safety on team performance.

Organizations increasingly need such situations and environments that can encourage increased team contributions through learning behavior, for example, voicing new ideas and collaborating in doing something to support team performance (Nembhard \& Edmondson, 2006). Stimulation of collective learning is expected to occur in team-based organizations (van Offenbeek, 2001). Collective learning can occur because team members interact with each other to share knowledge and skills, in order to be able to influence the efficiency and the effectiveness of team outcomes (Ellis, Hollenbeck, Ilgen, West, Porter, \& Moon, 2003). Teams can use internal and external knowledge resources to build collective knowledge structures (Curseu \& Pluut, 2018) that can support better team performance. Team learning is a fundamental mechanism in order to achieve team performance (Chan et al., 2003; Edmondson, 1999) because proactive team members discuss, identify and solve problems to achieve maximum team performance (Bunderson \& Sutcliffe, 2003). Based on this, we suspect that team performance can be influenced by team learning.

Improved team learning can improve team performance (e.g. Zellmer-Bruhn \& Gibson, 2006), but how the team learning influences 
team performance has not been extensively studied (van Woerkom \& van Engen, 2009), one of which is related to team monitoring which is proven to influence the process of achieving team performance (De Jong \& Elfring, 2010). Team monitoring in a positive perspective (Salas, Sims, \& Burke, 2005) is one form of team attention, aimed at achieving optimal team performance. This is due to team monitoring helping team members improve the team's performance in accordance with their role in the team (McAllister, 1995). Thus, team monitoring can encourage team learning so that it can improve team performance.

Meanwhile, the team's performance is evident in the study of Bergmann and Schaeppi (2016), and is strongly influenced by the team climate in the form of team psychological safety. This is interesting because the main determinant of team performance is not the dimension of monetary/financial incentives (e.g. Jenkins et al., 1998: Cascio \& Aguinis, 2008), but it is the nonmonetary factor, namely team psychological safety. On this basis, this study also examined team psychological safety's variables and their effects on team performance.

Initially, psychological safety is the level at which individuals feel safe and confident in their ability to deal with changes that occur in their organization (Schein \& Bennis, 1965). In the next stage, Kahn (1990) conceptualized psychological safety as an individual's perception of the comfort of performing and there is no worry about negative consequences for his/her status, self-image or career. In its development, it is treated as a climate at the team level, in the form of the shared team members' belief that the team is safe from potential interpersonal risks (Edmondson, 1999). This is relevant to the assumption of the social learning theory (SLT) (Bandura, 1977) about reciprocal links between the environment, behavior, and personal factors. Team psychological safety as a positive environment/climate can encourage team outcomes. With high levels of team psychological safety, team members feel safe to voice their ideas, provide honest opinions, collaborate, and experiment in doing the team's work (Edmondson \& Lei, 2014), so this study suspects that psychological safety can directly influence team performance.

Regarding team psychological safety, Pearsall and Ellis's (2011) study found different results from most other studies; their research found that high levels of psychological safety for the team were more likely to encourage unethical behavior if the team monitoring was weak. These findings indicate that team psychological safety is also influenced by the team monitoring mechanism. The social cognitive theory states that self-monitoring (of a team) influences one's motivation and actions (team members). The presence of monitoring can increase the team members' awareness of their own behavior (Bandura, 1991). Based on this, we believe that team monitoring can influence the team's psychological safety outcomes.

The main elements of team psychological safety are mutual trust (Edmondson, 1999), while monitoring teams with a positive perspective is positive behavior, and is a form of implementation that gets team members to trust each other (Salas et al., 2005). High levels of team psychological safety interactions and low levels of team monitoring encourage the accumulation of trust within the team so that it can cause a too-much-of-a-good-thing (TMGT) effect. The philosophical principle underlying the TMGT effect is that too many good things can have bad consequences (Pierce \& Aguinis, 2013). So, we believe that team monitoring can reduce the effect of TMGT on team psychological safety. Grossmana \& Feitosa 
(2018) explained that team monitoring that is perceived positively can improve team performance. This is in line with the perspective of TPWB (Barrick et al., 2013) which restates the importance of facilitation and limitation mechanisms as controls that affect whether an individual's perceived work effort is seen as having a meaningful impact on performance. Team monitoring can make team members more aware in order to increase their ability to synchronize their contributions to achieving team goals (Marks \& Panzer, 2004). Team monitoring enables irregularities in the performance of team members to be identified and corrected and provides a signal for improvements in supporting the team's performance. We suspect that the monitoring team can strengthen the influence of team psychological safety on team performance. This dampens the effect of TMGT (the accumulation of trust) in the team because of the implicit coordination mechanism (Rico, Sanchez-Manzanares, Gil, \& Gibson, 2008). In other words, high level of team psychological safety (representing high team trust) requires team monitoring as a control mechanism to achieve optimal team performance.

By integrating the basic premises of the SLT (Bandura, 1977), TPWB (Barrick et al., 2013) and TMGT (Pierce \& Aguinis, 2013), this study aims to examine the effects of team monitoring, team learning, and team psychological safety on team performance. Data were obtained from 215 respondents coming from 38 teams in higher education.

\section{LITERATURE REVIEW}

\section{Team Learning, Team Performance and Team Monitoring}

The social learning theory (Bandura, 1977) assumes that individual behavior is the result of reactions that arise as a result of interactions between cognitive processes, behaviors, and environmental contexts. All interact simultaneously, and either influence or are influenced by others. This theory also views the importance of conditioning (a positive environment) for team members. The literature interprets team learning to be a process as well as an outcome (Edmondson, 1999), although there is some literature only interprets it as an outcome (e.g., Van den Bossche et al., 2006), and as a process (e.g., Alcover, et al., 2004; van Offenbeek, 2001). This study views team learning to be both a result and a process, because team learning is a deliberative process where the team retrospectively evaluates its past performances with the aim of changing the process to produce a higher level of performance results (Rosen et al., 2011). Team learning behavior is a process of information seeking and reflective decision making (Rosen et al., 2011). The team looks for information, manages differences of opinion, and questions the assumption that problem solving is behavior that represents team learning activities (Edmondson, 1999). Collectively, this process encourages an increase in the information and knowledge available to team members, so as to create a comfortable climate and reduce the psychological risks associated with team learning (Hetzner et al. 2011).

The literature on team performance and team learning presents two different views. First, the view that team learning is juxtaposed with the results of the team's performance (e.g. ZellmerBruhn \& Gibson, 2006; Levitt \& March, 1988). This view assumes that when there is no change in performance it means that learning does not occur (Wilson et al., 2007). Second, the view that team learning is defined as a process for improving performance (e.g., Edmondson, 1999). This view assumes that to improve team performance, continuous reflection and action are needed to find solutions to problems that 
hinder the achievement of better team performance; when this process exists, the team learns (Edmondson, 1999). In relation to this, this study takes a more comprehensive look at it. Team members who reflect on work results, seek feedback, discuss mistakes to find solutions, and experiment can have an impact on improving performance (Edmondson, et al., 2007), so that it is seen as a process or work, because team learning is thought to improve team performance. This happens because team learning can help teams to improve their processes and find new and better ways to achieve the team's goals (Bunderson \& Sutcliffe, 2003). Based on this we suspect;

\section{Hypothesis 1:}

Team learning has a positive effect on team performance

The activity of team members to get new information in order to improve team results is one form of team learning. When explained in more detail, information's interpretation, distribution, acquisition, and storage are various activities in team learning (Huber, 1991; van Offenbeek (2001). Team dynamics can sometimes obscure the team's learning goals for each member, so we pay more attention to the control mechanisms to ensure that team learning can always support team performance. The social cognitive theory states that monitoring can influence one's actions and can increase the attention paid to one's own behavior, events, and their behavioral effects (Bandura, 1991). Complementing these assumptions, the theory of purposeful work behavior (TPWB) suggests that the work context can facilitate or limit the extent to which individuals express themselves so as to influence whether their perceived individual work effort is seen as meaningful (Barrick et al., 2013, p. 137). Therefore, team monitoring can maintain consistency in the team's learning goals. Team monitoring synchronizes the contribution of team members by helping them become more aware of the activities and performance of other, so as to maximize the achievement of the team's performance (Marks \& Panzer, 2004). Team monitoring involves intentional positive actions to control fellow teammates and help teammates to achieve the team's goals (De Jong \& Elfring, 2010). In other words, team monitoring is an implicit coordination mechanism that can improve the efficiency of the process of achieving team goals (Rico et al., 2008). Based on this, we suspect:

\section{Hypothesis 2:}

Team monitoring moderates the effect of team learning on team performance.

\section{Team Psychological Safety, Team Performance and Team Monitoring}

The literature on research into organizational behavior shows that the construction of psychological safety begins with a discussion of what is needed to face organizational change. In 1965, Schein and Bennis began to elicit this, in relation to employee behavior in response to organizational change. Kahn (1990) then conducted a qualitative study which showed that it affects individuals' desires to express themselves emotionally, cognitively, physically, and at work. When facing the reality of change, psychological safety can help overcome anxiety and teach people how to deal with the problems faced (Schein, 1993). The conception of psychological safety as a construct of the team climate (shared belief) formulated by Edmondson (1999), is a reference for researchers in conducting psychological safety studies to date. There are significant differences regarding the interpersonal climate of psychological safety between teams even within the same organization (Edmondson 1999). This finding 
proves that psychological safety is a team construct that has an important influence on team performance (Bergmann \& Schaeppi, 2016).

Confidence and comfort in the form of team psychological safety positively influence various proactive behaviors in the workplace (Detert \& Burris, 2007). Team psychological safety is needed in complex interactions to integrate the unique skills of team members in supporting team performance. This is reinforced by the findings of Bergmann and Schaeppi's (2016) research which shows that team psychological safety is a major factor that contributes to team results. The social learning theory (Bandura, 1977) assumes that there is a reciprocal effect between the environment, behavior, and personal factors. Based on this assumption, we believe that team psychological safety, as a positive environment/climate, can positively drive a team's results. With a high degree of team psychological safety, team members are not afraid to be themselves to voice ideas, collaborate, and experiment in teamwork (Edmondson \& Lei, 2014; Kahn, 1990). This can have a profound impact on the team's performance, because team psychological safety can build platforms that allow team members to have an opinion, exchange ideas and information, and encourage solutions to improve their team's performance (Bergmann \& Schaeppi's, 2016). Based on this, we suspect:

\section{Hypothesis 3:}

\section{Team psychological safety has a positive effect on team performance}

Team psychological safety and team monitoring are considered to have the same dimension; both have an element of shared trust. Edmondson (1999) states that team psychological safety is shown by mutual trust (shared belief) which can be interpreted as intrateam trust, and is a representation of team psychological safety. Meanwhile, Salas et al., (2005) explained that mutual trust in the team was related to team monitoring, which was related to intrateam trust (Langfred, 2004). Team monitoring is the awareness of the effort to control team members and steer them towards the work of other team members (Grossmana \& Feitosa, 2018). Trust and monitoring operate in reverse (Grossmana \& Feitosa, 2018). In other words, the level of trust in intrateam is a representation of low levels of monitoring and vice versa.

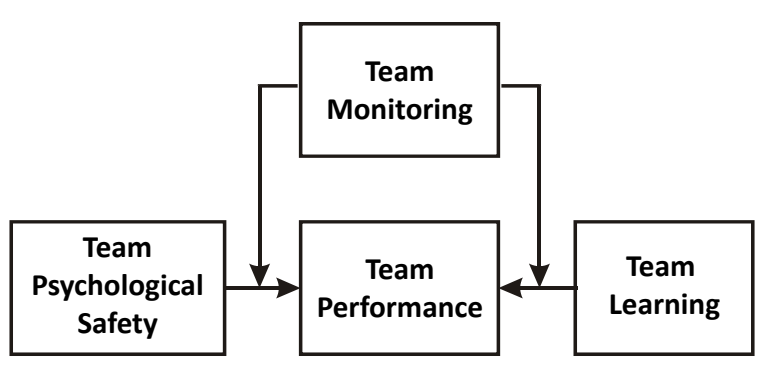

Figure. 1. Conceptual Model

Langfred's (2004) study found that low monitoring of teams can actually damage the team's outcomes. Low monitoring results in their being no control mechanism over potential job irregularities, which that can reduce performance. Based on the assumptions of the TMGT effect (Pierce \& Aguinis, 2013), we propose that the interaction of team psychological safety and team monitoring can cause the TMGT effects. The accumulation of trust causes TMGT effects. TMGT effect occurs when the positive predictor variable reaches the inflection point, where it reverses in a negative direction (Pierce \& Aguinis, 2013). The importance of team monitoring as a control mechanism refers to the perspective of TPWB (Barrick et al., 2013) which reinforces the importance of the facilitation and limitation mechanisms as controls which can influence whether an individual's perceived work effort is viewed as being meaningful and has an impact on performance. The moderate role of team 
monitoring is based on the integration of the TPWB and the perspective of the effects of the TMGT. When the team has a high level of team psychological safety, but a low level of team monitoring, then both contribute to the excessive accumulation of team trust. This excessive accumulation of team trust results in a TMGT effect. To avoid the TMGT's effect on team psychological safety, we propose that team monitoring is needed. In other words, when team psychological safety is high, team monitoring also needs to be improved. Based on this, we suspect:

\section{Hypothesis 4:}

Team monitoring moderates the influence of team psychological safety on team performance

\section{METHOD, DATA, AND ANALYSIS}

\section{Sample and data collection procedures}

This research was conducted using a survey approach (Neuman, 2007) through an online questionnaire distributed to lecturers at higher education institution in Indonesia. The lecturers filled in their perceptions of their home base study program as a team. Jehn et al. (2010) stated that team size influences team dynamics. Pavitand Broomell (2016) categorized teams into two sizes, namely small teams (4 to 7 members) and large teams (more than eight members). Van Knippenberg and Schippers (2007) warn the potential for an island (categorization) process within a team if the team is too large. So the team size that became the criterion in this study is a team with a minimum of four people. After verification, there were 215 respondents (in 38 teams) who met the criteria. Hair et al. (2014) stated that the number of samples required for a simple regression with one independent variable is a minimum of 30 samples, and 15 to 20 samples for a multiple regression. This study has four variables (independent and dependent) so there must be at least 120 respondents, so that 215 respondents meet the required minimum sample criteria. The respondents' profiles can be seen in Table 1. Sampling adequacy test results show that the KMO value $=0.906$ and the Bartlett test value with chi-squares $=210$ with a significance value at 0.000 . Therefore, the criteria and adequacy of the samples in this study have been met.

\section{Measures}

The measurement of all the variables in this study used measurements that have been employed before, so we needed to translate them in Indonesian, in accordance with the procedure of re-translation (Brislin, 1986). Measuring all of the variables in this study was done using a 6point Likert scale. This refers to the arguments of Trompenaars and Hampden-Turner (1997), which provide evidence that in some Asian countries, including Indonesia, the majority of respondents provide neutral answers (zero point on the favorable-unfavorable continuum), so the "neutral / middle" answers need to be avoided to minimize bias (Coper \& Schindler, 2003), so this study uses an even scale (six).

Table 1. Profile of Respondents

\begin{tabular}{|c|c|c|c|c|c|c|c|c|c|c|}
\hline & \multicolumn{2}{|c|}{ Sex } & \multicolumn{3}{|c|}{ Education } & \multicolumn{2}{|c|}{$\begin{array}{c}\text { Higher Education } \\
\text { Status } \\
\end{array}$} & \multicolumn{3}{|c|}{ When joining the team } \\
\hline & $\mathrm{F}$ & M & Bachelor & Master & Doctor & Public & Private & $<1$ year & $\begin{array}{l}1 \text { year to } \\
5 \text { years }\end{array}$ & $\begin{array}{c}\text { More } \\
\text { than } 5 \\
\text { year }\end{array}$ \\
\hline Amount & 92 & 123 & 7 & 174 & 34 & 136 & 79 & 26 & 63 & 126 \\
\hline Percentage $(\%)$ & $43 \%$ & $57 \%$ & $3 \%$ & $81 \%$ & $16 \%$ & $63 \%$ & $37 \%$ & $12 \%$ & $29 \%$ & $59 \%$ \\
\hline
\end{tabular}


We evaluated team psychological safety using five question items developed by $\mathrm{Li}$ and Tan (2012) adopted from May et al. (2004) and Edmondson (1999). A sample item includes "I am not afraid to express my opinions at work" and "I am not afraid to be myself at work". We measured team learning using seven question items (Edmondson, 1999)." A sample item is; "This team frequently seeks new information that leads us to make important changes". We drop one item; "This team tends to handle differences of opinion privately or off-line, rather than addressing them directly as a group" to improve the validity and reliability. To measure team monitoring we used five question items (De Jong \& Elfring, 2010). Sample items are; "In this team we watch whether everyone completes their work on time" and "In this team we check whether everyone meets their obligations to the team". Team performance variable was measured by five question items (Conger et al., 2000). A sample item includes "Most of our tasks are accomplished quickly and efficiently".

We conduct the validity and reliability test of the instruments. Hair et al (1998) provided a rule of thumb for assessing an instrument's validity: if the loading factor $(\lambda)$ values are above 0.5 , it (the validity) can be categorized as good. The results of our factor analysis show that 17 question items have a loading factor value $(\lambda)$ above 0.5 , while there are four question items that have a loading factor value $(\lambda)$ below 0.5 , but still above 0.4. Stevens (1992) recommends using a cut-off of 0.4 for an acceptable loading factor $(\lambda)$ value. Referring to this, the results of the validity test of our instruments are still acceptable. Regarding reliability, Sekaran (2003) provided an assessment that Cronbach's alpha values between 0.6 and 0.8 can still be accepted. The reliability test results showed good scores and were still acceptable, even TM and TP showed good reliability results above 0.90 . The results of the reliability test are Cronbach's alpha values for of team psychological safety $=0.60$; team learning $=0.8$ (to increase the reliability of the team learning variable, we dropped one question item, leaving six question items to produce a Cronbach's alpha of $\alpha=0.8$ ); team monitoring $=0.9$; and team performance $=0.9$. Sekaran (2003) provided an assessment that Cronbach Alpha values between 0.6 and 0.8 can still be accepted. Thus, all criteria and instrument requirements used in this study (validity and reliability) have been fulfilled.

\section{Aggregation Analyses}

We assess the suitability of the aggregation from individual data to team data by calculating within-group agreements and intraclass correlation coefficients using the formulas for Inter-rater agreement (IRA) and Inter-rater reliability (IRR) by Biemann et al. (2012). The $\operatorname{rwg}(j)$ value for all the variables exceeds the generally accepted 0.70 limit of $0.79 \leq \operatorname{rwg}(j) \leq$ 1.00, while the results of ICC (1) and ICC (2) can be seen in Table 2. The F-test results show all were significant at $0.00(\mathrm{p}<0.01)$, so the aggregation of the data at the team level was acceptable (Klein \& Kozlowski, 2000). Thus, all the criteria and instrument requirements used in this study have been fulfilled.

\section{RESULT AND DISCUSSION}

The regression analysis results of team learning on team performance showed a significance of $p$ $=0.00(\mathrm{p}<0.01)$ with a coefficient value of $\beta=$ 0.65 (see Table 2). The coefficient of determination ( $\mathrm{R}$ square) of team learning on team performance was 0.42 , which shows that team learning makes a contribution to team performance as by much as $42 \%$. Thus, $\mathrm{H} 1$ is supported. 
Table 2. Means, Standard Deviations, Correlations and Aggregation Indices

\begin{tabular}{|c|c|c|c|c|c|c|c|c|c|}
\hline \multirow{2}{*}{ Variable } & \multirow{2}{*}{$\mathbf{M}$} & \multirow{2}{*}{ SD } & \multirow{2}{*}{ (TPS) } & \multirow{2}{*}{$(\mathrm{TL})$} & \multirow{2}{*}{ (TM) } & \multirow{2}{*}{$\begin{array}{c}\text { Cronbach } \\
\text { Alpha }\end{array}$} & \multicolumn{3}{|c|}{ Aggregation Indices } \\
\hline & & & & & & & $\mathbf{r}_{\mathrm{wg}(\mathbf{j})}$ & ICC (1) & $\operatorname{ICC}(2)$ \\
\hline Team Psychological Safety (TPS) & 4.67 & 0.39 & - & - & - & 0.6 & 0.8 & 0.04 & 0.21 \\
\hline Team Learning (TL) & 4.32 & 0.46 & $0.34^{*}$ & - & - & 0.8 & 0.8 & 0.12 & 0.43 \\
\hline Team Monitoring (TM) & 4.34 & 0.44 & 0.21 & $0.67^{* *}$ & - & 0.9 & 0.8 & 0.02 & 0.10 \\
\hline Team Performance (TP) & 4.47 & 0.47 & $0.34^{*}$ & $0.65^{* *}$ & $.823^{* *}$ & 0.9 & 0.9 & 0.11 & 0.42 \\
\hline
\end{tabular}

Note: $\mathrm{n}=38$ teams, $* \mathrm{p}<0.05, * * \mathrm{p}<0.01$.

We tested $\mathrm{H} 2$ and $\mathrm{H} 4$ using bootstrapping techniques (Hayes, 2018) to analyze the moderating role of team monitoring. Bootstrapping techniques have the advantage of being more resistant, even with data abnormalities, so that it can overcome the weaknesses in the Sobeltest. Whereas the sobel test is often relied upon in the analysis of the causal steps of Baron and Kenny (1986). With these considerations in mind, we use a bootstrapping technique (Hayes, 2018). The results of the bootstrapping test of the moderating role of team monitoring in team learning on team performance can be seen Table 3 below.

The regression results of the interaction between team learning and team monitoring toward team performance show a value of $\mathrm{p}=$ 0.04 ( $p<0.05$ ). This means that the team monitoring has a proven moderation role, so that Hypothesis 2 is supported. Interestingly, the bootstrapping technique (Hayes, 2018) by default will divide the interaction effects of the moderating variables under low, moderate and high conditions. Graph 2 is an illustration of the results of the team monitoring's moderation role test in team learning on team performance.
The visualization of Figure 2 shows that the moderating effect of team monitoring under low, moderate and high conditions has different effects. When team monitoring is low, it can strengthen the effect of team learning on team performance, but when the team monitoring is high, team monitoring does not increase even though team learning increases.

The results of the regression of team psychological safety on team performance showed a significance of $\mathrm{p}=0.035(\mathrm{p}<0.05)$ with a coefficient value of $\beta=0.34$ (see Table $2)$. Thus, Hypothesis 3 is supported by the coefficient of determination ( $\mathrm{R}$ square) 0.12 . Meanwhile, the results of the regression of the interaction between team psychological safety and the team monitoring toward the team performance showed a value of $\mathrm{p}=0.41$ (this did not meet $\mathrm{p}<0.05$ ). This means that team monitoring does not have a moderating role in the influence of team psychological safety on team performance, so Hypothesis 4 is not supported. Figure 3 is an illustration of the results of the team monitoring's moderation role test in team psychological safety on team performance. 
Table 3. Bootstrapping Result

Model : 1

$\mathrm{Y}: \mathrm{TP}$ (Team Performance)

$X: T L$ (Team Learning)

W : TM (Team Monitoring)

Outcome variable : Team Performance

Model Summary

\begin{tabular}{lcccccc}
\hline \multicolumn{1}{c}{$\mathrm{R}$} & $\mathrm{R}$-sq & MSE & $\mathrm{F}$ & $\mathrm{df1}$ & $\mathrm{df2}$ & $\mathrm{p}$ \\
0.85 & 0.73 & 0.06 & 30.42 & 3.00 & 34.00 & 0.00 \\
\hline \multirow{4}{*}{ Model } & & & & & & \\
\hline \multirow{4}{*}{ Constant } & & & & & & \\
\cline { 2 - 7 } TL & coeff & se & $\mathrm{t}$ & $\mathrm{p}$ & LLCI & ULCI \\
TM & -6.41 & 3.31 & -1.93 & 0.06 & -13.14 & 0.33 \\
Int_1 & 2.76 & 0.76 & 2.30 & 0.03 & 0.20 & 3.31 \\
\hline
\end{tabular}

Product terms key: Int_1: TL x TM

Covariance matrix of regression parameter estimates:

\begin{tabular}{lcccc}
\hline & Constant & TL & TM & Int_1 \\
\cline { 2 - 5 } Constant & 10.98 & -2.50 & -2.55 & 0.58 \\
TL & -2.50 & 0.58 & 0.57 & -0.13 \\
TM & -2.55 & 0.57 & 0.61 & -0.13 \\
Int_1 & 0.58 & -0.13 & -0.13 & 0.03 \\
\hline
\end{tabular}

Test(s) of highest order unconditional interaction(s):

\begin{tabular}{cccccc}
\hline & $\mathrm{R} 2-\mathrm{chng}$ & $\mathrm{F}$ & $\mathrm{df} 1$ & $\mathrm{df} 2$ & $\mathrm{p}$ \\
$\mathrm{X} * \mathrm{~W}$ & 0.04 & 4.40 & 1.00 & 34.00 & 0.04 \\
\hline
\end{tabular}

Focal predict: TL (X), Mod var: TM (W)

Conditional effects of the focal predictor at values of the moderator(s):

\begin{tabular}{ccccccc}
\hline TM & Effect & $\mathrm{se}$ & $\mathrm{t}$ & $\mathrm{p}$ & LLCI & ULCI \\
\hline 3.90 & 0.32 & 0.14 & 2.30 & 0.03 & 0.04 & 0.61 \\
4.34 & 0.16 & 0.12 & 1.32 & 0.20 & -0.09 & 0.41 \\
4.78 & 0.00 & 0.15 & -0.02 & 0.99 & -0.30 & 0.30 \\
\hline
\end{tabular}




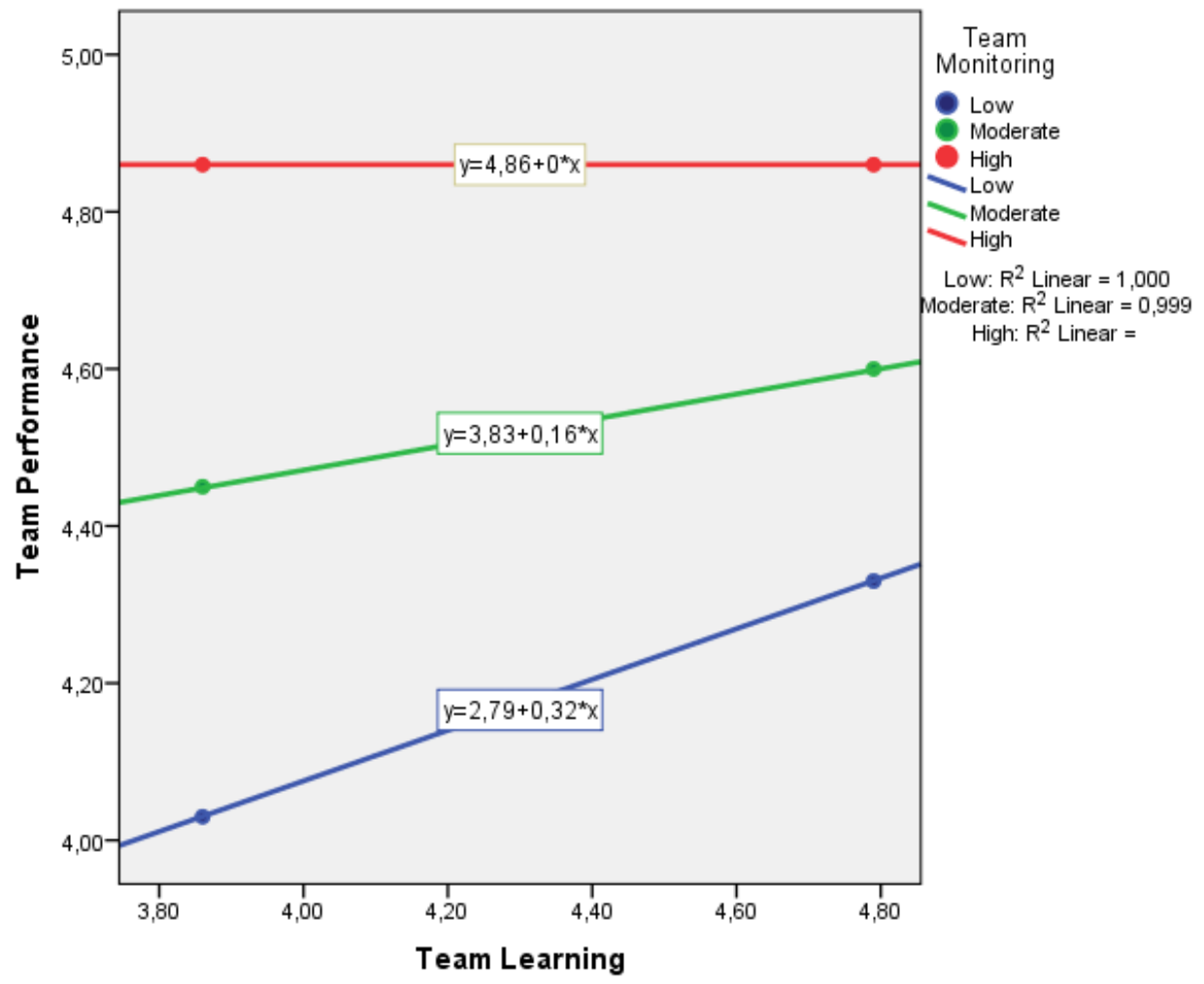

Figure 2. Slope for Interactive Effect of TL and TM on TP

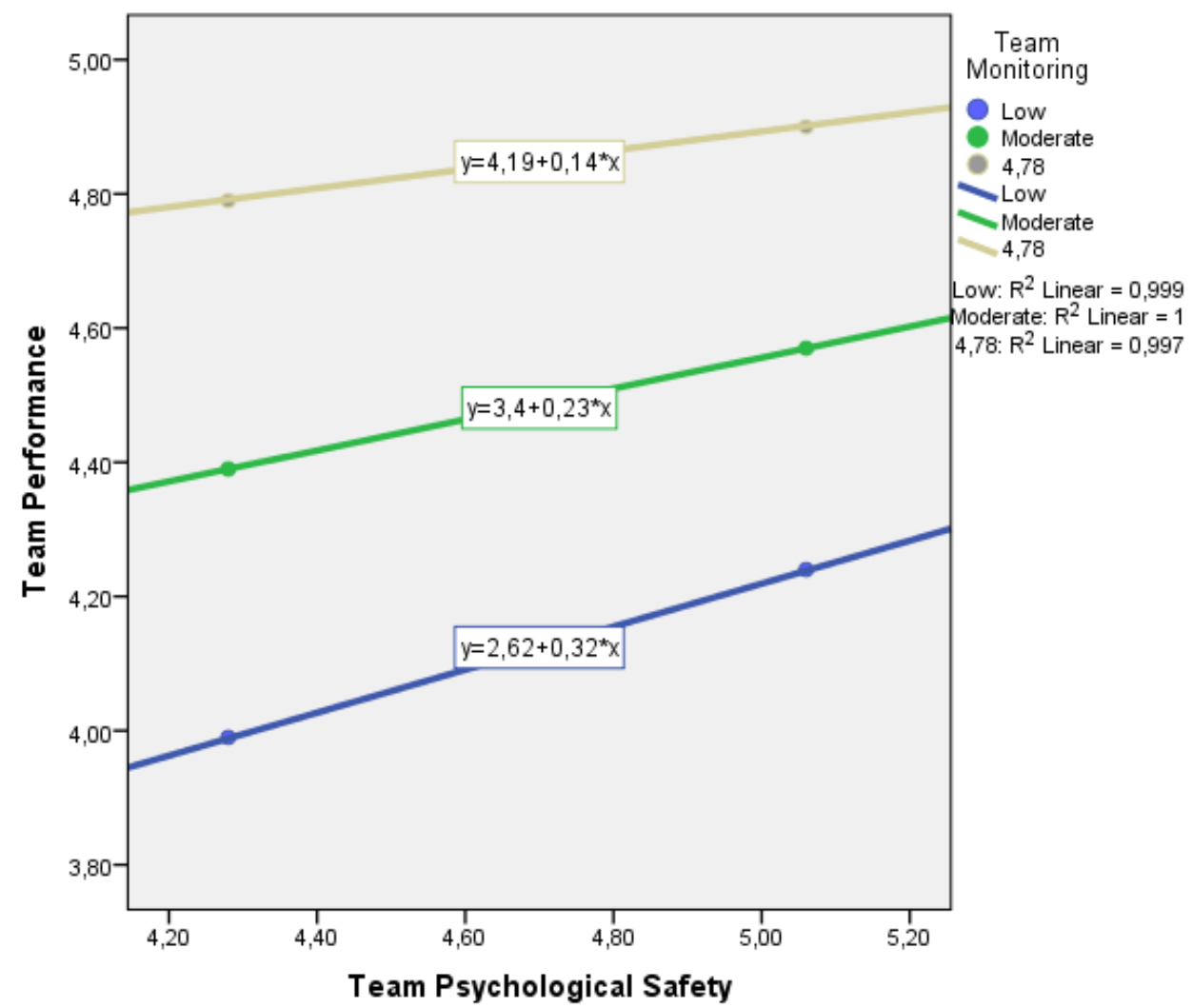

Figure 3. Slope for Interactive Effect of TPS and TM on TP 
The slope in Figure 3 shows that when team monitoring is low, moderate or high, it does not have any effect on the influence of team psychological safety on team performance. Thus this study showed that the interaction of team monitoring and team psychological safety has no impact on team performance.

\section{CONCLUSION AND SUGGESTION}

This study contributes by providing new evidence about the role of the team monitoring on team performance. This research also contributes by providing new insights relating to team monitoring and its interaction in team learning and team psychological safety on team performance. In the previous literature, team monitoring is interpreted both negatively and positively. Team monitoring can be interpreted negatively, as a form of mistrust in the team (Grossman \& Feitosa, 2018), but it can also be interpreted positively, as a control effort to assist team members in carrying out team tasks (de Jong \& Elfring, 2010). Despite the differences in interpretation, this study sees that team monitoring can provide feedback and can identify potential errors early on, because it involves team members observing each other's actions (Marks et al., 2001). This finding (H2) provides new insights and evidence that a low level of team monitoring can have a positive effect for team learning on team performance, but in the case of a team with a high level of team monitoring, it does not have an effect on team performance even though team learning does increase. This is in line with the philosophical principle underlying the TMGT effect; that too many good things can have bad consequences (Pierce \& Aguinis, 2013). Team monitoring within certain levels can have a positive impact on team performance, but if the team monitoring levels are too high it can actually harm the team, because team learning does not have a positive effect on team performance.

Team psychological safety has been proven to be able to directly influence team performance (e.g., Li \& Tan, 2012) and indirectly through team learning (e.g., Liu et al., 2014), but we tested the two separately. Based on data from 215 respondents who are members of 38 teams in higher education establishments, this research presents evidence that team learning (H1) and team psychological safety (H3) directly influence team performance. Apart from debates related to team monitoring, whether as a result (Zellmer-Bruhn and Gibson, 2006) or as a permanent change (Ellis et al., 2003), this finding (H1) provides evidence that team learning directly influences team performance. Team learning can help teams find new ways, and adapt to new things to produce better team performances (Bunderson \& Sutcliffe, 2003).

This study provides evidence that the interaction between team monitoring and team learning has a role in influencing team performance $(\mathrm{H} 2)$, but in its interaction with team psychological safety, the moderating role of team monitoring (H4) is not supported. We suspect that this is related to the stages of a team's development. Tuckman (1965) models the stages of team development from forming, then toward storming, then toward norming and finally performing. Research by McGrew et al. (1999) about team age shows that the norming stage is reached when the team's age is over 2 years old. In the norming stage, team members have accepted the team's norms and the team's affective ties have been formed (Tuckman, 1965), this is relevant to the level of team psychological safety. If seen by the length of time since joining the team, the respondents in this study (215 respondents) are divided into three categories: $12 \%<1$ year; $29 \%$ from 1 to 5 years; and $59 \%>5$ years. It is expected that most 
teams in this study have reached the norming stage, and perhaps even the performing stage. When a team has reached the norming and performing stages, team monitoring does not provide a moderating effect on team performance. It can be a trigger for other researchers to be able to develop a study into the role of team monitoring covering the team's age and development which influences team performance.

\section{LIMITATIONS AND FUTURE DIRECTIONS}

This study is limited to examining team monitoring and its interactions with team learning and team psychological safety on team performance. More extensive exploration is needed related to other variables that influence team performance, such as team autonomy. Autonomy is one of the dimensions of psychological empowerment (Thomas \& Velthouse, 1990). Team autonomy is the degree to which teams feel free when in doing work and they can choose different ways to do their work (Kirkman, 1999). Team autonomy at a certain point can have a positive effect on performance, but the TMGT effect occurs when the normally useful antecedent reaches the inflection point (H2). The inflection point is a specific context caused by excessive conditions (Pierce \& Aguinis, 2013). How team monitoring and its interactions with other variables have a role in influencing team performance is a gap that still needs to be revealed. The dynamics of team monitoring and its influence on team performance is an exciting new chapter to be followed up more extensively.

\section{IMPLICATIONS}

The findings of this study are that positive team performance is directly affected by team learning (H1), while team psychological safety (H3) can be taken into consideration by organizational managers to improve team performance in organizations. Organizations need to create/build a comfortable climate to allow teams to convey ideas, provide honest feedback, collaborate, and experiment when working (Edmondson \& Lei, 2014) so that team learning and team psychological safety can be created to encourage maximum team performance.

Regarding team monitoring, this finding can act as a reference for managers that at certain levels team monitoring can improve team performance, but too much team monitoring actually has no influence on team performance. Managers (organizational/university leaders) need to consider setting team monitoring policies at a precise level to get the maximum possible team performance, as the main support of organizational competitiveness.

\section{REFERENCE}

Bandura, A. (1977). Self-efficacy: Toward a unifying theory of behavioral change. Psychological Review, 84, 191-215.

Bandura, A. (1991). Social cognitive theory of self-regulation. Organizational Behavior and Human Decision Processes, 50(2), 248-287.

Baron, R. M., \& Kenny, D. A. (1986). The moderator-mediator variable distinction in social psychological research: Conceptual, strategic, and statistical considerations. Journal of Personality and Social Psychology, 51, 1173-1182

Bergmann, B., \& Schaeppi, J. (2016). A datadriven approach to group creativity. Harvard Business Review, 12, 43-62.

Barrick, M.R., Mount, M. K., \& Li, N. (2013). The theory of purposeful work behavior: The role of personality, job characteristics, and experienced meaningfulness. Academy of Management Review, 38, 132-153.

Biemann, T., Cole, M. S., \& Voelpel, S. (2012). Within-group agreement: On the use (and 
misuse) of rwg and $\operatorname{rwg}(\mathrm{j})$ in leadership research and some best practice guidelines. The Leadership Quarterly, 23, 66-80.

Brislin, R. W. (1986). The wording and translation of research instruments. In W. J. Lonner, \& J. W. Berry (Eds.). Field methods in cross-cultural research (pp. 137-164). Beverly Hills, CA: Sage

Bunderson, J.S. and Sutcliffe, K.M. (2003), "Management team learning orientation and business unit performance", Journal of Applied Psychology, 88,552-60.

Carlos-Maria Alcover, C.M., Gil. F., \& Á. Barrasa. (2004). Team learning: Adaptation of learning activities scales in a Spanish sample. Psicothema, 16(3), 378-383

Cascio, W. F., \& Aguinis, H. (2008). Research in industrial and organizational psychology from 1963 to 2007: Changes, choices, and trends. Journal of Applied Psychology, 93, 1062-1081.

Chan, C.C.A., Pearson, C. and Entrekin, L. (2003),"Examining the effects of internal and external teamlearning on team performance", Team Performance Management: An International Journal, 9 (7), 174-181

Conger, J. A., Kanungo, R. N., \& Menon, S. T. (2000). Charismatic leadership and follower effects. Journal of Organizational Behavior, 21(7), 747-767.

Cooper, DR. \& PS. Schindler. 2003. Business Research Methods. 8th ed. New York. McGraw Hill.

Curseu, P. L., \& Pluut, H. (2018). A systematic investigation of absorptive capacity and external information search in groups. Team Performance Management: An International Journal. 24 (7/8), 411-434

Detert, J. R., \& Burris, E. R. (2007). Leadership behavior and employee voice: Is the door really open? Academy of Management Journal, 50, 869-884.

De Jong, B. A., \& Elfring, T. (2010). How Does Trust Affect the Performance of Ongoing Teams? The Mediating Role of Reflexivity,
Monitoring, and Effort. Academy of Management Journal, 53(3), 535-549.

Dirks, K. T., \& Ferrin, D. L. 2001. The role of trust in organizational settings. Organization Science, 12: 450-467.

Edmondson, A. C., \& Lei, Z. (2014). Psychological safety: The history, renaissance, and future of an interpersonal construct. The Annual Review of Organizational Psychology and Organizational Behavior, 1, 2343.

Edmondson, A. (1999). Psychological safety and learning behavior in work teams. Administrative Science Quarterly, 44, 350383.

Edmondson, A. C., Dillon, J. R., \& Roloff, K. S. (2007). Three perspectives on team learning: Outcome improvement, task mastery, and group process. Academy of Management Annals, 1, 269-314.

Ellis, A.P.J., Hollenbeck, J.R., Ilgen, D.R., West, B.J., Porter, C.O.L.H. and Moon, H. (2003), "Team learning: collectively connecting the dots", Journal of Applied Psychology, 88 (5), 821-35.

Grossman, R., \& Feitosa, J. (2018). Team trust over time: Modeling reciprocal and contextual influences in action teams. Human Resource Management Review, 28(4), 395-410.

Hair JF, Tatham RL, Anderson RE and Black W. (1998). Multivariate data analysis. (Fifth Ed.) Prentice-Hall:London.

Hair, J. F., Black, W.C. Babin, B.J. \& Anderson R.E. (2014).Multivariate data analysis, 7 th Eds. Person New International Edition, Harlow; Pearson Education limited.

Hayes, A. F. (2018). Introduction to Mediation, Moderation, and Conditional Process Analysis: A Regression-Based Approach Second Edition. New York: Guilford Press

Hetzner, S., Heid, H., \& Gruber, H. (2012). Change at work and professional learning: How readiness to change, self-determination and personal initiative affect individual learning through reflection. European 
Journal of Psychology of Education, 27(4), 539-555.

Huber, G.P. (1991), "Organizational learning: the contributing processes and the literatures", Organizational Science, 2, 88-115.

Jehn, K. A., Rispens, S., \& Thatcer, S. M. B. (2010). The Effect of Conflict asymmetry o work group and individual outcomes. Academy of Management Journal, 53(3): 596.

Jenkins, G. D., Jr., Mitra, A., Gupta, N., \& Shaw, J. D. (1998). Are financial incentives related to performance? A meta-analytic review of empirical research. Journal of Applied Psychology, 83, 777-787

Kahn, W. A. (1990). Psychological conditions of personal engagement and disengagement at work. Academy of Management Journal, 33, 692-724.

Kerr, N. L., \& Tindale, R. S. (2004). Group Performance and Decision Making. Annual Review of Psychology, 55(1), 623-655.

Kirkman, B.L. (1999). Beyond self-management: Antecedents and consequents of team empowerment. Academy of Management Journal, 42, 58-74.

Klein, K. J., \& Kozlowski, S. W. J. 2000. From micro to meso: Critical steps in conceptualizing and conducting multilevel research. Organizational Research Methods, 3: 211-236.

Kozlowski, S. W. J., \& Chao, G. T. (2012). The Dynamics of Emergence: Cognition and Cohesion in Work Teams. Managerial and Decision Economics, 33(5-6), 335-354.

Langfred, C.W. (2004). Too much of a good thing? Negative effects of high trust and individual autonomy in self-managing teams. Academy of Management Journal, 47, 385-399.

Levitt, B. and March, J.G. (1988), "Organizational learning", Annual Review of Sociology, 14, 319-40.

Li, A. N., \& Tan, H. H. (2012). What happens when you trust your supervisor? Mediators of individual performance in trust relationships. Journal of Organizational Behavior, 34, 407-425.

Liu, S., Hu, J., Li, Y., Wang, Z., \& Lin, X. (2014). Examining the cross-level relationship between shared leadership and learning in teams: Evidence from China. The Leadership Quarterly, 25, 282-295.

Marks, M. A., \& Panzer, F. J. 2004. The influence of team monitoring on team processes and performance. Human Performance, 17(1): 25-41.

May, D. R., Gilson, R. L., \& Harter, L.M. (2004). The psychological conditions of meaningfulness, safety and availability and the engagement of the human spirit at work. Journal of Occupational and Organizational Psychology, 77, 11-37.

Mayer, R. C., \& Gavin, M. B. 2005. Trust for management and performance: Who minds the shop while the employees watch the boss? Academy of Management Journal, 48: 874-888.

McAllister, D. J. 1995. Affect-and cognitionbased trust as foundations for interpersonal cooperation in organizations. Academy of Management Journal, 38: 24-59.

Mcgrew, J. F., Bilotta, J. G., \&Deeney, J. M. (1999). Software Team Formation and Decay. Small Group Research, 30(2), 209234.

Nembhard, I. M., \& Edmondson, A. (2006). Making it safe: The effects of leader inclusiveness and professional status on psychological safety and improvement efforts in health care teams. Journal of Organizational Behavior, 27, 941-966.

Neuman, W.L. (2007). Basics of Social Research Methods: Qualitative and Quantitative Approaches. 2nd Edition, Allyn and Bacon, Boston.

Pavitt, C., \& Broomell, L. (2015). Group Communication During Resource Dilemmas: 4: The Effect of Group Size. Human Communication Research, 42(1). 
Pearsall, M. J., \& Ellis, A. P. J. (2011). Thick as thieves: The effects of ethical orientation and psychological safety on unethical team behaviour. Journal of Applied Psychology, 96, 401-411.

Pierce, J. R., \& Aguinis, H. (2013). The toomuch-of-a-good-thing effect in management. Journal of Management, 39, 313-338.

Rico, R., Sanchez-Manzanares, M., Gil, F., \& Gibson, C. 2008. Team implicit coordination processes: A team knowledge-based approach. Academy of Management Review, 33: $163-184$

Rosen, L.D., Lim, A.F., Carrier L.M., and Cheever. N.A. (2011) An Empirical Examination of the Educational Impact of TextMessage-Induced Task Switching in the Classroom: Educational Implications and Strategies to Enhance Learning. Psicología Educativa. 17 (2); 163-17.

Salas, E., Stagl, K. C., \& Burke, C. S. (2004). 25 years of team effectiveness in organizations: research themes and emerging needs. International Review of Industrial and Organizational Psychology, 19, 47-92.

Salas, E., Sims, D. E., \& Burke, C. S. (2005). Is there a "Big Five" in teamwork? Small Group Research, 36(5), 555-599.

Schein, E. H., \& Bennis, W. (1965). Personal and organizational change through group methods. New York: Wiley.

Schein, E. H. (1993). On dialogue, culture, and organizational learning. Organizational Dynamics, 22(2), 40-51.

Sekaran, U. (2003).Research Methods for Business: A Skill-Building Approach. 4th Edition, John Wiley \& Sons, New York

Stevens JP. (1992). Applied multivariate statistics for the social sciences (2nd edition). Hillsdale, NJ: Erlbaum.
Thomas, K.W., \& Velthouse, B.A. (1990). Cognitive elements of empowerment: An "interpretive" model of intrinsic task motivation. Academy of Management Review, 15, 666-681.

Trompenaars, F., and C. Hampden-Turner. 1997. Riding The Waves of Culture: Understanding Cultural Diversity in Business. 2nd ed. London. Nicholas Brealey.

Tuckman B. W., (1965), 'Developmental Sequence in Small Groups', Psychological Bulletin 63.

Van den Bossche, P., Gijselaers,W. H., Segers, M., \& Kirschner, P. A. (2006). Social and cognitive factors driving teamwork in collaborative learning environments: Team learning beliefs and behaviors. Small Group Research, 37, 490-521.

van Knippenberg, D., \& Schippers, M. C. (2007). Workgroup diversity. Annual Review of Psychology, 58, 515-541

Van Offenbeek, M. (2001). Processes and outcomes of team learning. European Journal of Work and Organizational Psychology, 10, 303-317

van Woerkom, M. \& van Engen, M. (2009), "Learning from conflicts? The relationships between task and relationship conflicts, team learning and team performance", European Journal of Work and Organizational Psychology, 6, 1464-643.

Wilson, J. M., Goodman, P. S., \& Cronin, M. A. (2007). Group learning. Academy of Management Review, 32(4), 1041-1059.

Zellmer-Bruhn, M. and Gibson, C. (2006), "Multinational organization context: implications for team learning and performance", Academy of Management Journal, 49, 50118. 